Jan Kochel ${ }^{1}$

Uniwersytet Opolski

\title{
Lekcja religii szansą dla ewangelizacji
}

Papież Franciszek zapowiedział temat nowego synodu biskupów poświęconego młodzieży: „Młodzież, wiara i rozeznanie powołania” (Rzym, październik 2018). W dokumencie przygotowawczym kard. Lorenzo Baldisseri zachęcał, by towarzyszyć młodym w „przyjęciu radości Ewangelii w naszych czasach, które naznaczone są niepewnością

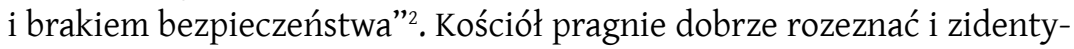
fikować najbardziej skuteczne sposoby głoszenia młodym Dobrej Nowiny. Do tego koniecznie potrzebne są osoby, będące dla młodzieży punktami odniesienia: najpierw rodzice, później duszpasterze, osoby konsekrowane, nauczyciele i inni wychowawcy. „Osoby te muszą posiadać autorytet, jasną tożsamość ludzką, solidną przynależność kościelną, widoczną jakość duchową, żywą pasję wychowawczą i głęboką zdolność rozeznawania. Odpowiedzialność zaś spoczywa na całej wspólnocie wierzą-

1 Ks. Jan Kochel - kapłan diecezji gliwickiej, prof. dr hab nauk teologicznych w zakresie katechetyki; kierownik Katedry Antropologii i Teologii Rodziny na Wydziale Teologicznym Uniwersytetu Opolskiego; rzeczoznawca ds. podręczników przy Komisji Wychowania Katolickiego KEP, redaktor strony Szkoły Słowa Bożego (www.ssb24.pl); członek Èquipe Européenne de Catéchèse (EEC), European Forum for Religious Education in Schools (EuFRES); jkochel@uni.opole.pl.E-mail: jkochel@uni.opole.pl.

2 Por. http://www.deon.pl/religia/serwis-papieski/aktualnosci-papieskie/ art,5257,papiez-zdecydowal-o-temacie-kolejnego-synodu.html/ (14.01.2017). 
cych” - przekonuje kard. Baldisseri. Sekretarz generalny synodu wskazał również na miejsca i narzędzia tego towarzyszenia młodym. „Miejscami działań duszpasterskich są według niego: życie codzienne, zajęcia dla młodych, Światowe Dni Młodzieży, wydarzenia diecezjalne, parafie, oratoria, uniwersytety, szkoły katolickie, wolontariat, działalność społeczna, ośrodki duchowości, doświadczenia misyjne, pielgrzymki, pobożność ludowa, a także «świat cyfrowy», który otwiera nowe możliwości, ale też przynosi nowe zagrożenia. Narzędziami z kolei są m.in. sposoby wyrazu właściwe młodym, wychowanie, modlitwa, cisza, kontemplacja"3. Jak widać, w tym procesie rozeznania wyraźnie wskazani są nauczyciele i wychowawcy oraz najbliższe środowisko ludzi młodych, w tym szkoła i katecheza szkolna. Pytania, które się rodzą, są następujące: Czy dostrzegliśmy szansę nowej ewangelizacji - głoszenia radosnej, Dobrej Nowiny (Ewangelii) w polskiej szkole? Jakiej katechezy potrzebują dzieci i młodzież w dobie ponowoczesności? Jakiego katechety - nauczyciela wychowawcy koniecznie potrzeba? Jakich narzędzi należy użyć, by być skutecznym w głoszeniu? Oto pytania problemowe, na które warto poszukać odpowiedzi.

\section{Jak towarzyszyć młodym w przyjęciu Ewangelii?}

Wielu katechetów i wychowawców wciąż kontestuje powrócenie katechezy do polskiej szkoły. Są tacy, którzy nadal zastanawiają się: czy jest to szansa, czy zagrożenie dla jej tożsamości oraz żywotności Kościoła w naszym kraju? Niebawem minie 40 lat naszej „wędrówki po pustyni polskiej szkoły”. Jest to czas rozeznawania - oczyszczenia - prób/kryzysów - nowych wyzwań (Wj 12, 51 - 40, 38; por. J 21, 1-25). Czy mamy pełną świadomość kondycji pasterzy/nauczycieli oraz wspólnoty/uczniów? Jako punkt odniesienia dla tego itinerarium warto przyjąć opowiadanie z 21 rozdziału Ewangelii św. Jana; mowa jest w nim o połowie na jeziorze

3 http://www.deon.pl/religia/serwis-papieski/aktualnosci-papieskie/ art,5257,papiez-zdecydowal-o-temacie-kolejnego-synodu.html/ (14.01.2017). 
i sytuacji uczniów przed spotkaniem ze zmartwychwstałym Panem ${ }^{4}$. Sięgamy do intuicji biblijnej kard. Carla Marii Martiniego († 2012), który zauważył, że „św. Jan przedstawia drogę świadomości zbiorowej, drogę rozpoczynającą się w chwili rozbicia, niepewności i zamieszania, a zmierzającą do budowania jedności" ${ }^{\text {" D }}$ Dostrzegamy w tym analogię do sytuacji naszej katechezy szkolnej.

Tekst ewangeliczny autor dzieli na cztery części. Pierwsza część przedstawia rozbicie świadomości. Apostołowie - zagubieni po śmierci Jezusa, jeszcze niebędący jednością - idą razem łowić ryby, bardziej z konieczności niż z miłości. Nie została jeszcze odbudowana wśród nich mocna więź jedności. Tłem dla sytuacji rozbicia i konfliktu różnych osobowości są noc, poczucie zakłopotania, zmęczenie, zimno, nieudany połów, rozczarowanie.

W naszych realiach szkolnych widoczne są brak jedności między nauczycielami i wychowawcami, zmęczenie czy wypalenie zawodowe, brak efektów nauczania, dobrej atmosfery i współpracy; rozczarowania, pretensje do władz, autorów podręczników i pomocy dydaktycznych. Taką sytuację obrazuje nocny połów apostołów, którzy, owszem, znajdują się jeden obok drugiego, ale nie są zespoleni miłością, raczej czują się zobowiązani do wspólnej pracy, być może zaczynają się kłócić tej nocy, bo nic nie ułowili, obwiniają Piotra, który ich zaprosił, gdy tymczasem winę ponoszą inni, nieumiejący łowić. Jest to więc sytuacja ludzi podzielonych i zagubionych.

Drugi moment nadchodzi o świcie, gdy Jezus zjawia się na brzegu jeziora, ożywia i buduje na nowo jedność, nadając sens byciu razem. Czyni to najpierw przez dyskretną radę, później poprzez cudowny, zaskakujący czyn, wreszcie stopniowo daje się rozpoznać. Wspólnota na nowo się zawiązuje, odzyskuje siłę i entuzjazm.

Są takie momenty odnowy - mobilizacji w naszej posłudze katechetycznej: dni skupienia, rekolekcji, drobne zwycięstwa, przejawy

4 Por. C. M. Martini, „To jest Pan!”. Rekolekcje dla osiemnastolatków, tłum. H. Musiał, Kraków 1994.

5 C. M. Martini, Ludu mój, wyjdź z Egiptu, tłum. S. Obirek, Kraków 1989, s. 14; por. C. M. Martini, KochaćJezusa. Medytacja nad Ewangelią św. Jana, tłum. A. Sobejko, Kraków 2003, s. $156-161$. 
docenienia, satysfakcji z pracy, nawrócenia wśród uczniów, ich dobre osiągnięcia lub życiowe wybory (powołania).

Trzeci moment - Jezus zaprasza apostołów do wspólnoty stołu i objawia się jako Pan wspólnoty. Ten stół zawiera w sobie, w sposób oczywisty, ucztę eucharystyczną, a więc całą działalność wspólnototwórczą Chrystusa w Jego Kościele.

To czas, kiedy udaje się nam przygotować i doprowadzić swoich uczniów do przyjęcia sakramentów, do świadomego uczestnictwa w nich; kiedy widzimy swoich uczniów zaangażowanych w życie wspólnot, ruchów i stowarzyszeń; jako wolontariuszy czy aktywnych uczestników Światowych Dni Młodzieży.

Czwartym momentem jest nadanie władzy pasterskiej Piotrowi - władzy jako służby wspólnocie. Jezus pyta Piotra o miłość, nawiązuje osobistą więź i budzi świadomość pasterską w imię misji - służby wspólnocie wierzących (por. J 21, 15-19)6.

Ostatni etap to model uświadomienia własnej misji jako służby pasterskiej. Warto pamiętać o tych czterech momentach: pozwalają nam ujrzeć drogę, którą chcemy przejść z Jezusem, a także istotę misji katechety - ewangelizatora.

W procesie nauczania, wychowywania i towarzyszenia młodym konieczne jest scalenie osobowości katechety i ucznia. „Świadomość zatomizowana to postrzeganie siebie, zarówno jednostkowe (moje życie), jak i wspólnotowe (moja parafia, mój Kościół, moje miasto, mój naród, moja ojczyzna) - jako rzeczywistości rozbitej, pokawałkowanej, niespójnej. Widzimy siebie nie jako jedność, w której wszystko jest zespolone i promieniuje mocą i entuzjazmem, lecz czujemy rozbicie, zgrzyt, rozklejenie, a to prowadzi do niezadowolenia, złośliwości, zgorzknienia, pretensji, rywalizacji i urazów. To właśnie jest świadomość zatomizowana: świadomość, która jest wezwana do jedności, a która - przeciwnie - rozbija się na tysiące atomów"7.

6 C. M. Martini, Ludu mój, wyjdź z Egiptu, dz. cyt., s. 14-15.

C. M. Martini, Ludu mój, wyjdź z Egiptu, dz. cyt., s. 15n; por. M. Quoist, Modlitwa i czyn, przeł. Maria Brygida, Warszawa 1984, s. 181n. 
Mamy własne modele formacji jako antidotum na świadomość zatomizowaną, np. pedagogię nowego człowieka sługi Bożego ks. Franciszka Blachnickiego († 1986). Ta rodzima pedagogia wypracowana w ramach Ruchu Światło-Życie daje konkretną odpowiedź w obrębie pedagogiki katolickiej. Odpowiedzią pedagogii oazowej na rozbicie, błędy i zagrożenia jest kształtowanie człowieka (nowego) zintegrow a ne go, który dzięki wychowaniu osiągnie jedność między prawdami i zasadami poznawanymi, uznawanymi za słuszne a wyznawanymi i stosowanymi w życiu. Jedność prawdy i życia (wiary) integruje człowieka wewnętrznie ${ }^{8}$.

Podobne rozwiązania proponuje włoski pedagog, psycholog i kierownik duchowy Amedeo Cencini FdCC (kanosjanin), przekonując, że proces formacji składa się zasadniczo z trzech elementów oddziaływania pedagogicznego: wychowania, formacji, towarzyszenia9. Przede wszystkim towarzyszenie wychowawcze i duchowe jest dziś antidotum na atomizację, zagubienie i wyobcowanie młodych.

Papież Franciszek zwrócił na to uwage w adhortacji o głoszeniu Ewangelii w dzisiejszym świecie oraz w dialogu z polskimi biskupami podczas podróży apostolskiej z okazji Światowych Dni Młodzieży Kraków 2016. W Evangelii gaudium pisał o osobistym towarzyszeniu procesom wzrostu: „Kościół będzie musiał wprowadzić swoich członków - kapłanów, zakonników i świeckich - do tej «sztuki towarzyszenia», aby wszyscy nauczyli się zawsze zdejmować sandały wobec świętej ziemi drugiego" (EG 169) ${ }^{10}$. Młodzi potrzebują nauczania, które wprowadza w osobowe relacje, uczy szacunku i empatii, nauczania o znamionach wychowawczych i terapeutycznych. Koniecznie potrzeba pedagogiki towarzyszenia - „«pedagogiki prowadzącej osoby, krok po kroku, do pełnego przyswojenia sobie tajemnicy». Aby dojść do dojrzałości, czyli aby osiągnąć zdolność do naprawdę wolnych i odpowiedzialnych decyzji, nieodzowny jest czas i ogromna cierpliwość" (EG 170).

8 F. Blachnicki, Charyzmat „Światło-Życie”. Teksty podstawowe, [Krościenko] 1987, s. 27-39; por. J. Kochel, Pedagogia Nowego Człowieka ks. Franciszka Blachnickiego, „Katecheta” 60 (2016) z. 3, s. 135-143.

9 Por. A. Cencini, Od wychowania do formacji, Kraków 20052.

10 Franciszek, adhort. apost. Evangelii gaudium [dalej: EG]. 
Podobnie brzmi apel Franciszka skierowany na Wawelu do polskich biskupów: „Przeżywamy religijny analfabetyzm [...], który myli jedno z drugim. I do tego trzeba katechezy, katechezy życia, katechezy, która daje nie tylko pojęcia, ale towarzyszy w pielgrzymowaniu. Towarzyszenie jest jedną z najważniejszych postaw! Towarzyszenie wzrostowi wiary. Jest to wspaniała praca i młodzi ludzie tego oczekują! Młodzi ludzie czekają... "Ale jeśli zacznę mówić, to się znudzą!». Ależ trzeba im dać zadanie do wykonania [...]. Niech zaczną odczuwać, że są przydatni. I pozwólmy, aby tutaj padło Boże ziarno. Powoli. Ale nie można tego uczynić tylko słowami! Współczesnemu analfabetyzmowi religijnemu musimy stawić czoło za pomocą trzech języków: języka umysłu, języka serca i języka rąk. Wszystkie trzy w harmonijnej jedności"11. Wydaje się, że ten papieski postulat oferuje program, który angażuje młodych, dając im katechezę życia oraz pedagogię wychowawczego i duchowego towarzyszenia nasyconego sokiem ewangelicznym i sporządzoną przy użyciu języka przystosowanego do czasu i osób (por. EN 54, DOK 194; EG 158-168).

\section{2. Środowisko szkolne i parafialne w procesie nowej ewangelizacji}

Powrót katechezy do polskich szkół, czyli nauczania i wychowania $\mathrm{w}$ wierze (por. CT 18) ${ }^{12}$, okazał się naturalny i budzący nadzieję. Opinie specjalistów katechetyki i samych katechetów są pozytywne, "przyjęta strategia sprawdzała się, a ewentualne wątpliwości są absolutnie możliwe do zmodernizowania przez wielu zaangażowanych ludzi w to wielkie dzieło edukacji religijnej młodego pokolenia w naszej Ojczyźnie" - przekonuje ks. Marian Zając z KUL-u ${ }^{13}$.

W Polskim Dyrektorium Katechetycznym podkreślono, że „nowa sytuacja, w jakiej znalazła się polska katecheza po roku 1990, powinna

11 Franciszek, Błogosławieni miłosierni. Słowa do młodych, Kraków 2016, s. 42.

12 Jan Paweł II, adhort. apost. Catechesi tradendae [dalej: CT].

13 M. Zając, Wprowadzenie, w: XXV lat nauczania religii w polskiej szkole. Między nadzieja a rzeczywistościa, red. M. Zając, Lublin 2015, s. 10. 
budzić i pogłębiać refleksję, że nauczanie religii w szkole jest szansą dla ewangelizacji, ponieważ dla niektórych ochrzczonych, zdystansowanych do wiary, szkolne lekcje religii są jedynym miejscem spotkania z Ewangelią, ze świadkami wiary, jakimi są katecheci i uczniowie głęboko wierzący [...] gdzie mogą usłyszeć głos Kościoła i gdzie dokonać się może wyjaśniające wprowadzenie w liturgię i modlitwę Kościoła" $\left(\right.$ PDK 57) ${ }^{14}$.

W tym samym dyrektorium poświęcono cały rozdział tematowi Duszpasterstwa katechetyczne w parafii (por. PDK 97-117), przypominając, że „musi [ono] mieć charakter ciągły w tym sensie, że katecheza dzieci, młodzieży i dorosłych nie mogą być terenami oddzielonymi od siebie czy pozbawionymi wzajemnej łączności. Trzeba, aby one między sobą się wspierały i uzupełniały" (PDK 97; por. CT 45). Katecheza szkolna musi być wspierana przez duszpasterstwo katechetyczne w parafii, we wspólnotach, ruchach i stowarzyszeniach kościelnych, ale i na odwrót: duszpasterstwo katechetyczne musi wspierać katechezę szkolną, zwłaszcza w szkołach katolickich (por. DWCH 5-9) ${ }^{15}$.

Intensywne badania teoretyczne i empiryczne potwierdzają potrzebę wymiaru ewangelizacyjnego katechezy w szkołach, chociaż wciąż poszukiwany jest model takiej katechezy w opcji ewangelizacyjnej ${ }^{16}$. Wiąże się on jednak ściśle z osobą katechety - ewangelizatora.

14 Konferencja Episkopatu Polski, Dyrektorium katechetyczne Kościoła Katolickiego w Polsce, Kraków 2001 [dalej: PDK].

15 Sobór Watykański II, Deklaracja o wychowaniu chrześcijańskim, w: Sobór Watykański II, Konstytucje, dekrety, deklaracje, Poznań 20022 [dalej: DWCH]; por. Formacja głosicieli Ewangelii. Jak przygotować katechetów - nauczycieli religii do podjęcia nowej ewangelizacji?, red. W. Lechów, Szczecin 2015 (Studia i Rozprawy, 38).

${ }_{16} \mathrm{~W}$ ostatnim czasie powstało kilka prac doktorskich na temat wymiaru ewangelizacyjnego katechezy, np. W. Rzeszowski, Odnowa katechezy $w$ świetle ewangelizacyjnych zadań Kościoła nakreślonych w encyklice Jana Pawła II „Redemptoris misio”, Warszawa 2001; G. Puchalski, Katecheza w kontekście nowej ewangelizacji w nauczaniu Jana Pawła II, Olsztyn 2002; P. Skiba, Katecheza ewangelizacyjna w nowych ruchach $i$ wspólnotach kościelnych. Studium katechetyczne wybranych ruchów i wspólnot kościelnych, Lublin 2006; P. Napieralski, Katecheza nadziei dla młodych w nauczaniu Jana Pawła II, Zielona Góra 2011; A. Szkatuła, Katecheza inicjacyjna $w$ gimnazjum. Studium teoretyczno-empiryczne, Opole 2012; G. J. Zakrzewski, Ewangelizacyjna odnowa formacji chrześcijańskiej w Polsce. Studium katechetyczne w świetle adhortacji „Evangelii gaudium”, Lublin 2016; por. Katecheza ewangelizacyjna $w$ rodzinie, 
Jan Paweł II postulował ewangelizację nową „w swym zapale, w swych metodach, w swym wyrazie” 17 , a Franciszek apeluje o „ewangelizatorów z ducha”: „Ewangelizacja z duchem różni się bardzo od całości zadań przeżywanych jako ciężki obowiązek, który po prostu się toleruje lub znosi jako coś, co sprzeczne jest z własnymi skłonnościami i pragnieniami. Jak bardzo chciałbym znaleźć odpowiednie słowa, aby zachęcić do ewangelizacji bardziej gorliwej, radosnej, ofiarnej, śmiałej, zawsze pełnej miłości i zdolnej do zarażania innych!" - wyznaje papież. Od razu jednak dodaje: „Z drugiej strony wiem, że żadna motywacja nie będzie wystarczająca, jeśli w sercach nie żarzy się ogień Ducha. Tak więc ostatecznie ewangelizacja z ducha jest ewangelizacją z Ducha Świętego, ponieważ to On jest duszą ewangelizującego Kościoła" (EG 261).

Środowisko szkolne - jak zresztą każde inne - może ożywić (zewangelizować) tylko takie treści, taka dynamika, metody i środki, którymi posłużyli się katecheci czy ewangelizatorzy natchnieni Bożym Duchem. Wymownym tego przykładem jest pierwsza ewangelizacja w dzień Pięćdziesiątnicy (por. Dz $2-4$ ).

Przy użyciu jakiej metody głosili oni słowo Boże? Ich zasadniczą metodą było głoszenie słowa Bożego i nawiązywanie relacji w ramach wspólnoty. Głoszone słowo - również w warunkach szkolnych - jest słowem Jezusa, lecz zawsze w kontekście relacji z kimś, kto słucha. Jeśli szkoła (publiczna czy katolicka) jest znaczącym miejscem formacji ludzkiej, to może też być miejscem formacji duchowej - ewangelizacji. Jaki jednak model ewangelizacji może sprawdzić się w szkole?

Włoski biblista Augusto Barbi wyróżnia cztery modele ewangelizacji, które funkcjonowały w Kościele pierwotnym:

- model profetyczny (znaki i słowa),

- model kerygmatyc zny (rozeznanie historii zbawienia),

parafii, szkole, red. S. Dziekoński, Warszawa 2002; Ewangelizować czy katechizować, red. S. Dziekoński, Warszawa 2002; A. Offmański, Koncepcja katechezy o charakterze ewangelizacyjnym według zasad katechumenatu, Szczecin 2010; Katecheza ewangelizacyjna. Poszukiwanie koncepcji, red. P. Mąkosa, Lublin 2010; Nowa ewangelizacja w nowej katechezie, red. P. Mąkosa, Rzeszów 2013.

17 Jan Paweł II, Przemówienie podczas Zgromadzenia Plenarnego CELAM, 9 marca 1983, Portau-Prince, Haiti, „L'Osservatore Romano” (wyd. pol.) 1983 nr 4, s. 29. 
- model a gory (dialog w kontekście pluralistycznym),

- model towarzyszenia (kompetencja hermeneutyczna) ${ }^{18}$.

Pierwszy model podkreśla fakt, że często relacje ze słuchaczem nawiązuje się za pomocą bezpośredniego znaku, np. cudu. W czwartym rozdziale Dziejów Apostolskich Piotr przed Sanhedrynem dokonuje cudu uzdrowienia chromego, by posłużyć się nim jako obiektywnym znakiem, dla podkreślenia nowości głoszonej nauki: „Rozsądźcie sami, co jest słuszne przed Bogiem: was słuchać czy Boga? Bo nie możemy milczeć o tym, cośmy widzieli i słyszeli" (Dz 4,19n) ${ }^{19}$. Katechezie ewangelizacyjnej powinno towarzyszyć profetyczne przekonanie o misji zleconej przez samego Boga, której wyrazem są moc słowa i przekonujące znaki, np. nawrócenie - uzdrowienie - nowe życie w Chrystusie.

Drugi model domaga się otwarcia na działanie „przyobiecanego przez Ojca Ducha Świętego, którego teraz zesłał, jak sami widzicie i słyszycie" (Dz 2, 33b). Aktywne zaangażowanie w nauczanie i świadectwo sprawia, że Duch wchodzi w bezpośredni kontakt ze słuchaczami. Posłany przez Jezusa Zmartwychwstałego jest widzialny i słyszalny, On pomaga głosić pierwszy kerygmat (por. EG 160-175)20. Duch jest sprawcą wydarzeń, sytuacji, dzięki którym orędzie staje się zrozumiałe i żywe (aktualne). Katecheza ewangelizacyjna powinna ukazywać historię zbawienia „za pośrednictwem katechezy biblijnej, pozwalającej poznać czyny i słowa, przez które Bóg objawił się ludzkości: wielkie etapy Starego Testamentu, przez które przygotował drogę Ewangelii; życie Jezusa, Syna Bożego, wcielonego w łonie Maryi, który przez swoje czyny i nauczanie

18 A. Barbi, Modelli di evangelizzazione a partire della prassi della prima comunitá cristiana, „Credere Oggi” 32 (2012) 191, s. 54-67; por. F. Blachnicki, Została nam powierzona Ewangelia. Wykłady z kerygmatyki czyli teorii ewangelizacji, Kraków 2007; Nowa ewangelizacja. Kerygmatyczny impuls w Kościele, red. P. Sowa, K. Kaproń, Gubin 2012 (Seria Nowej Ewangelizacji); J. H. Prado Flores, Formacja uczniów, tłum. M. Bigiel, Łódź 1992; J. H. Prado Flores, Nowi ewangelizatorzy dla Nowej Ewangelizacji, tłum. B. K. Jakubowski, Poznań 2013; J. H. Prado Flores, Idźcie i ewangelizujcie ochrzczonych, tłum. B. K. Jakubowski, Poznań 2016; S. Dyk, Nowa ewangelizacja. Konkretne wyzwanie, Gubin 2015; S. Hahn, Nieście i przyjmujcie Dobrą Nowinę. Wyzwania Nowej Ewangelizacji, tłum. M. Bilikiewicz, Poznań 2015.

19 C. M. Martini, Żyć wartościami Ewangelii, tłum. M. E. Nowak, Wrocław 1999, s. 27-29.

20 J. Kochel, Kerygmat jako treść nowej ewangelizacji, w: Nowa ewangelizacja w nowej katechezie, dz. cyt., s. 23-30; J. Kochel, Język kerygmatyczny w przekazie wiary, „Biuletyn Edukacji Medialnej" 1 (2014), s. 55-70. 
doprowadził Objawienie do pełni; historię Kościoła, która przekazuje Objawienie" (DOK 108) ${ }^{21}$.

Trzeci model podkreśla aktualność Pisma Świętego szczególnie dla tych (słuchaczy), którzy przyjmują jego orędzie i podejmują dialog ze światem (pluralistycznym) 22. To działanie jest głoszone „dzisiaj” (por. Łk 4, 21; 5, 26; Dz 17, 30)23, a Pismo Święte staje się kontekstem dla bezpośredniości tego orędzia.

Czwarty model skierowany jest do tych, którzy nie potrafią odczytać znaków i nie chcą słuchać słowa Bożego. Wychodzi się wtedy od powszechnego przeży cia religijne go, od umiejętnego towarzyszenia i rozeznawania ich sytuacji życiowej (inkulturacji). Przykładem jest nauczanie Pawła na Areopagu w Atenach (por. Dz 17, 16-34). Apostoł Narodów musiał wykazać się wszechstronną kompetencją hermeneutyczną i dydaktyczną, aby dotrzeć z orędziem Ewangelii o Jezusie i zmartwychwstaniu do różnych adresatów ${ }^{24}$. Katecheza ewangelizacyjna musi w świetle słowa Bożego reagować na aktualne problemy i wyzwania oraz podejmować trud osobistego towarzyszenia procesom nawrócenia i pozyskiwania uczniów. Papież Franciszek przekonuje: „Musimy nadać naszej drodze zdrowy rytm bliskości, wraz ze spojrzeniem okazującym szacunek i pełnym współczucia, które jednak jednocześnie będzie leczyło, wyzwalało i zachęcało do dojrzewania w życiu chrześcijańskim" (EG 169).

Interesujące w kontekście środowiska szkolnego czy parafialnego są nie tyle sam uniwersalny charakter modeli ewangelizacyjnych czy DOK].

${ }^{21}$ Kongregacja ds. Duchowieństwa, Dyrektorium ogólne o katechizacji, Poznań 1998 [dalej:

${ }^{22}$ Por. Ł. Kamiński, Aktualizcja Pisma Świętego według dokumentu Papieskiej Komisji Biblijnej „Interpretacja Biblii w Kościele” jako nowy sposób odniesienia słowa Bożego do życia, „Ruch Biblijny i Liturgiczny" 69 (2013) 3, s. 197-215.

${ }^{23}$ Łukaszowe „dziś/dzisiaj” wyraża głęboką prawdę, że Jezus jest centralną postacią całej historii zbawienia; por. T. Jelonek, Zbawcze znaczenie Łukaszowego „dzisiaj”, „Ruch Biblijny i Liturgiczny” 28 (1975) 3, s. 107-113; S. Włodarczyk, Realizacja zbawczego „dziś” w Chrystusie. Sēmeron w soteriologii Łukasza, Lublin 1989; S. Haręzga, Słowo o „dziś”, „Pastores” 36 (2007) 3, s. 7-15; J. Kochel, Katecheza misyjna w Ewangelii Łukasza i Dziejach Apostolskich. Biblijnokatechetyczne studium narracyjne, Opole 2013, s. 62-69 (Opolska Biblioteka Teologiczna, 133).

${ }_{24}$ J. Kochel, Katecheza misyjna w Ewangelii Łukasza i Dziejach Apostolskich..., dz. cyt., s. $124-130$. 
poszczególne przykłady na istnienie znaku, Ducha, Pisma Świętego i przeżycia religijnego, ile fakt, że w misji ewangelizacyjnej zawsze mamy odniesienie do życia chrześcijańskiego przeżywanego wspólnie: dzieła Ducha najpełniej ukazują się w żywej wspólnocie ${ }^{25}$. Jeśli uda się stworzyć wspólnotę uczniów w ramach katechezy szkolnej czy parafialnej, to możliwe okaże się również głoszenie kerygmatu w tych środowiskach. I tam w ustach katechety - ewangelizatora winien wybrzmieć ke ryg mat - pierwsze orędzie: „Jezus Chrystus cię kocha, dał swoje życie, aby cię zbawić, a teraz jest żywy u twego boku codziennie, aby cię oświecić, umocnić i wyzwolić" (por. EG 164).

We wspólnocie gotowej do przyjęcia kerygmatu nieodzowny staje się nauczyciel - ewangelizator. Nie ma tego terminu w Piśmie Świętym. Jest zaś „głosiciel Ewangelii” (gr. euangelistēs - „zwiastujący dobrą (szczęśliwą) nowinę, krzewiciel Ewangelii") ${ }^{26}$. Taki sługa słowa posiada szczególne dary (charyzmaty) „badania/wyjaśniania tajemnicy Chrystusa” (Ef 3, 9.18n) oraz „budowania Ciała Chrystusa” (Ef 4,11n). Dary te z jednych czynią a p os tołó w, zinnych prorokó w, zinnychjeszcze e wangelistów albo pasterzy lub nauczycieli $($ Ef 4,11$)$. „Apostoł to ten, który kładzie pierwszy fundament pod wspólnotę i powołuje ją do życia; prorok wyjaśnia zamiary Boga w stosunku do wspólnoty; e w an gelist a głosi orędzie, kerygmat, Dobrą Nowinę i w ten sposób przyłącza do wspólnoty Kościoła nowych wiernych, urzeczonych Słowem zbawienia [tajemnicą Chrystusa]; paster z chroni i prowadzi zgromadzoną owczarnię, n a u c zy c ie l umacnia - przez katechezę, naukę i teologię - to wszystko, co stanowi o istocie wspólnoty"27. W osobie ewangelizatora dostrzegamy zatem istotne dary (charyzmaty) budujące wspólnotę uczniów.

Współczesny katecheta - ewangelizator ma świadomość, że mimo wielu wysiłków „nie wszyscy posłuchali Ewangelii” (Rz 10, 16), a z drugiej strony jednak spełniają się słowa proroka: „Znaleźli mnie ci, którzy mnie

25 Por. C.M. Martini, Żyć wartościami Ewangelii, dz. cyt., s. 29.

26 R. Popowski, Wielki słownik grecko-polski Nowego Testamentu, Warszawa 1995, s. 240; por. C. M. Martini, Głosiciel Ewangelii u św. Łukasza, tłum. S. Obirek, Kraków 1993, s. 12-14; J. Kochel, Z. Marek, Pedagogia biblijna w katechezie, Kraków 2012, s. 137-146.

27 C.M. Martini, Głosiciel Ewangelii u św. Łukasza, dz. cyt., s. 12. 
nie szukali, ukazałem się tym, którzy o mnie nie pytali" (Iz 65, 1; por. Rz 10, 20). Dlaczego Ewangelia może znaleźć swoją drogę do każdego i wszystkich?

Odpowiada na to pytanie Apostoł Narodów w Liście do Rzymian: „Dla wszystkich jest jeden i ten sam Pan, hojny dla tych, którzy Go wzywają. Każdy bowiem, kto wezwie imienia Pana, zostanie zbawiony. Ale jak mieli wzywać Tego, w którego nie uwierzyli? W jaki sposób mieli uwierzyć w Tego, którego nie słyszeli? Jak mieli słyszeć, jeśli nikt im nie głosił? Jak mieli głosić, skoro nie zostali posłani? Tak oto jest napisane: «Jak bardzo oczekiwane są stopy tych, którzy zwiastują dobro!» [...]. Wiara więc rodzi się ze słuchania, słuchanie natomiast ma miejsce dzięki słowu Chrystusa" (Rz 10, 12b-17 BP).

Model dzisiejszej katechezy musi uwzględnić oczekiwania co do języka, jakim będzie się posługiwać. Dobra Nowina może być głoszona w różnych językach, ale zrozumiana i przyjęta będzie jedynie w tym języku, który odbiorcy uznali za własny ${ }^{28}$. Stąd w posłudze katechetycznej potrzeba pamiętać o prymacie słowa Bożego, które „zawsze posiada swą wyższość i skuteczność, zwłaszcza gdy niesie ze sobą moc Bożą" (EN 42) ${ }^{29}$.

\section{Metoda katechezy w sytuacji pluralizmu i złożoności}

Katecheza szkolna i parafialna coraz częściej korzysta z metod i środków wypracowanych w ramach szkół nowej ewangelizacji ${ }^{30}$. Łączą one w sobie wspomniane elementy biblijnego modelu nauczania i wychowania w wierze, tj. znak, Duch Święty, Pismo Święte i przeżycie religijne.

28 A. Potocki, Katecheza wobec współczesnych wyzwań, w: Katecheza dziś, red. J. Zimny, Sandomierz 2002, s. 58.

29 Paweł VI, adhort. apost. Evangelii nuntiandi [dalej: EN].

30 Por. M. Widenka, Kerygmatyczne szkoły nowej ewangelizacji $w$ Polsce jako praktyczna realizacja wezwania Jana Pawła II do Nowej Ewangelizacji, Katowice 2010; M. Widenka, Fenomen katolickich kerygmatycznych szkót nowej ewangelizacji, „Studia Pastoralne” 6 (2010), s. 257-287; W. Szlachetka, Fenomen szkół nowej ewangelizaacji. Studium socjologiczno-pastoralne, Kraków 2011; M. Królikowski, Aktywno-uczestnicząca metoda kursów nowej ewangelizacji. Podstawy teoretyczne i praktyczne, „Przegląd Homiletyczny” 17 (2013), s. 147-157. 
W kontekście społeczeństwa informatycznego ważne są również metody multimedialne w katechezie ${ }^{31}$.

Szkoła Nowej Ewangelizacji Jezusa Zmartwychwstałego w Gliwicach aktywnie uczestniczy w przygotowaniu młodzieży szkolnej do sakramentu bierzmowania, organizując kursy i rekolekcje w oparciu o własne materiały ${ }^{32}$. W tym kręgu opracowano również prezentację multimedialną na temat ewangelizacyjnej metody katechezy pt. „Gry wojenne”. Ewangelizacja w katechezie ${ }^{33}$.

Prezentacja nawiązuje do popularnej wśród dzieci i młodzieży tematyki wojskowej oraz stylistyki gier komputerowych ${ }^{34}$.

Ewangelizacja w katechezie nosi znamiona kampanii wojennej (strategii) pojmowanej metaforycznie. Apostoł Paweł organizował taką strategię, znał swoich towarzyszy broni (por. Flp 2, 25; Flm 2), najbliższego współpracownika Tymoteusza nazywał „dobrym żołnierzem” (gr. stratiōtēs - $2 \mathrm{Tm} 2,3 \mathrm{n}$ ), a uczniom zalecał, by przyoblekli do walki duchowej pełne „uzbrojenie (oręż / zbroję Bożą)” (gr. hopla / pan-oplia por. Rz 6, 13; 13, 12; 2 Kor 6, 7; 10, 4; Ef 6, 10-20; 1 Tes 5, 8; 1 P 4, 1) $)^{35}$.

31 Por. A. Zakrzewski, Dlaczego trzeba wizualizować katechezę - naukę „religii” w szkole?, „Katecheta” 42 (1998) nr 8, s. 76-79; A. Zakrzewski, Prezentacja multimedialna w katechezie, „Katecheta” 45 (2001) nr 9, s. 11-22; A. Niwiński, Środki informacyjne w katechetycznej działalności Kościoła, Kraków 2004.

32 A. Sepioło, J. Kasperczyk, Młodzi na progu. Materiały do pracy z młodzieża przy parafii. Przygotowanie do bierzmowania, Gliwice 2010; Młodzi na progu. Materiały dla animatorów. Przygotowanie do bierzmowania, Gliwice 2010; Twoje codzienne „Minuty przed Bogiem”. Ćwiczenia, Gliwice 2010; por. A. Sepioło, Jak pomóc bierzmowanym zostać w Kościele? Doświadczenie diecezji gliwickiej, „Homo Dei” 84 (2015) nr 2, s. 43-51.

33 Autorem prezentacji jest ks. Artur Sepioło - dyrektor Szkoły Nowej Ewangelizacji „Jezusa Zmartwychwstałego” w Gliwicach, dyrektor Sekcji ds. Nowej Ewangelizacji Kurii Diecezji Gliwickiej, przewodniczący Krajowej Rady Dyrektorów Kerygmatycznych Szkół Nowej Ewangelizacji, autor m.in. Nowa ewangelizacja. Śladami Jana Pawła II, Kraków 2001; Walka o wiarę, Gliwice 2015.

34 José H. Prado Flores w kursie Sekret Pawła, poświęconym formacji ewangelizatorów, posługuje się metaforyką sportową; por. Sekret Pawła. Zawodnik Jezusa Chrystusa, tłum. M. Bigiel, Łódź 2007.

35 J. Wilk, Charakterystyka i zadania przełożonych wspólnoty chrześcijańskiej według Listów Pasterskich. Studium biblijno-pragmatyczne, Katowice 2015, s. 167-175 (Studia i Materiały WT UŚ w Katowicach, 81). 
Pierwszym etapem strategii ewangelizacyjnej powinno być wstępne „szkolenie taktyczne”, którego celem jest pielęgnowanie właściwej mentalności (postawy) nauczycieli ewangelizatorów:

- działaj z wiarą w zwycięstwo;

- nie stawaj w kontrze przeciw wszystkim;

- bądź zdecydowany, ale cierpliwy.

Taki obóz szkoleniowy ma znamiona pus ty n i, służy przygotowaniu intelektualnemu i duchowemu.

Drugi etap wiąże się z o c eną sytua cji - rozeznaniem środowiska, adresatów, możliwości przepowiadania. Planowanie musi zakładać działanie długofalowe („długa perspektywa”), np. 35 spotkań ewangelizacyjnych lub krótkofalowe („krótki czas reakcji”), np. w ramach konkretnej jednostki lekcyjnej, kiedy ewangelizator ma 30 sekund na znalezienie skutecznej treści i narzędzia oddziaływania ewangelizacyjnego. Nauczyciel ewangelizator musi rozeznać: kogo ma przed sobą?

- wymieszane towarzystwo (wierzący i kontestatorzy),

- rozpoznanie przeciwnika (świadomość i zainteresowania).

Właściwa ocena sytuacji (rozeznanie) wiąże się z taktyką. Dobry dowódca, zanim podejmie walkę, charakteryzuje swoich przeciwników oraz strategię tego, co chciałby osiągnąć (por. Łk 14, 31-33). Określenie możliwości swojej armii wiąże się ze znajomością „wyposażenia”. To regularny przegląd uzbrojenia - pełnej zbroi/oręża. Nauczyciel ewangelizator musi wiedzieć: co należy głosić?

- kerygmat,

- świadectwo,

- Ewangelię.

Program nauczania ewangelizacyjnego jest niezmienny: „Nie trzeba zatem wyszukiwać «nowego programu» - przekonywał Jan Paweł II. Program już istnieje: ten sam, co zawsze, zawarty w Ewangelii i żywej Tradycji. Jest on skupiony w istocie rzeczy wokół samego Chrystusa, którego mamy poznawać, kochać i naśladować, aby żyć z Nim...”36.

36 Jan Paweł, List apostolski Novo millennio ineunte [dalej: NMI], 29. J. H. Prado Flores przekonuje, że kerygmat ewangelizacyjny powinien obejmować sześć tematów wzajemnie ze sobą powiązanych: a) miłość Boża, b) grzech człowieka, c) propozycja zbawienia, 
Język, środki wyrazu i narzędzia przekazu ewangelizacyjnego muszą być dostosowane do czasu i osób (por. EN 54, DOK 194). Trzeba też korzystać z metod aktywizujących i środków multimedialnych, np.:

- film,

- prezentacje,

- piosenki,

- rekwizyty (pomoce dydaktyczne).

Trzeci etap katechezy w procesie ewangelizacji to właściwa „akcja” ewangelizacyjna, którą autor Dziejów Apostolskich określił jako „[przemawianie] z wielkim zapałem i [nauczanie] dokładnie tego, co dotyczyło Jezusa" (Dz 18, 25). W sytuacji pluralizmu i złożoności środowisk nieodzowna staje się katecheza ewangelizacyjna, w ramach której nauczyciel ewangelizator musi pamiętać:

- o świadomości celu („Nie daj się ściągnąć [z obranej drogi]; ustępuj, gdy trzeba; zapisz, co na jutro");

- punkcie zaczepienia („Zainteresowanie ich życiem, odnajdywanie w nich dobra, burzenie mitów");

- elastyczności („Przewidywane mutacje, rozmowa”);

- elementach zaskoczenia („Zmiana środowiska, współpraca ze specjalistami, werbunek we własnym szeregu - grupy, wspólnoty, stowarzyszenia").

- zaproszeniu („Na spotkanie, pielgrzymki, rekolekcje, kursy”).

Ewangelizacja w katechezie domaga się mądrej kampanii (strategii). Przypomina ewangelicznego króla, który nim wyruszy na wojnę, siada i rozważa plany bitwy, dokonuje przeglądu armii i uzbrojenia (por. Łk 14, 31-33). Jego celem jest nie tyle zwycięstwo w jednej potyczce, ile ostateczne rozstrzygnięcie wojny, zdobycie królestwa niebieskiego (zbawienie). Mądra strategia przewiduje działanie $\mathrm{z}$ wiarą w zwycięstwo, ale nie za wszelką cenę, nie przez stawanie w kontrze przeciw wszystkim; czasem trzeba poszukiwać warunków pokoju, zawsze jednak należy działać

d) wiara i nawrócenie, e) Duch Święty, pieczęć gwarantująca skuteczność działania, f) wspólnota, w której przeżywane jest zbawienie; por. J. H. Prado Flores, Sekret Pawła..., dz. cyt., s. 99-114. 
zdecydowanie, lecz cierpliwie. Istotne jest, by uważnie wsłuchiwać się w echo słowa Bożego (por. Łk 14, 35) ${ }^{37}$.

\section{Zakończenie}

Wykorzystanie szansy ewangelizacji w ramach katechezy szkolnej wiąże się z rozeznaniem duchowym, które jest darem Ducha Świętego. Rozeznanie duchowe - znane z Biblii oraz duchowej tradycji chrześcijańskiej - oznacza wysiłek wewnętrzny, pozwalający ocenić, dostrzec, odróżnić wśród wielu możliwych postaw ludzkich te, które pochodzą, oraz te, które nie pochodzą od wewnętrznego tchnienia Ducha Świętego ${ }^{38}$. Jeśli to wszystko, co czyni się w Kościele, jest autentyczne, to pochodzi od Ducha Świętego, który odnawia i dynamizuje życie wspólnot chrześcijańskich (por. 2 Kor 5, 17; Ap 21, 5). Z darem rozeznania duchowego łączy się pedagogika towarzyszenia, która również ma swoje korzenie w Piśmie Świętym i pedagogicznej tradycji chrześcijańskiej ${ }^{39}$. Promotorem tak rozumianej pedagogii jest papież Franciszek, który konsekwentnie zachęca młodych, by „powstali z kanap i z odwagą wyruszyli na peryferia" ${ }^{40}$, niekoniecznie związane z ewangelizacją odległych krajów. Ewangelizacji czy reewangelizacji potrzebują najczęściej

37 Pierwotne znaczenie „katechezy” według Jana Pawła II: „[...] Kościół «trwa w nauce Apostołów», a trwanie takie oznacza spotkanie w wierze tych, którzy nauczają, i tych, którzy bywają nauczani. To jest właśnie katecheza, wedle greckiego słowa katecheō. Słowo to znaczyło pierwotnie «wołać z góry» (ex alto), również «wywoływać echo» (katà = z góry, echeō = brzmieć, wypowiadać). Późniejsze znaczenie: pouczać (gdy głos nauczyciela jest świadomym niejako echem pytania ucznia, a odpowiedź ucznia - echem nauczyciela)"; por. Wierze w Boga Ojca Stworzyciela, Città del Vaticano 1987, s. 13.

38 C. M. Martini, Słownik duchowy. Mały przewodnik dla duszy, tłum. H. Bzikot, Kraków 1999, s. 130n; E. Bianchi, Sztuka rozeznania duchowego, „L'Osservatore Romano” 37 (2017) 9, s. $49-50$.

39 Por. Z. Marek, Pedagogika towarzyszenia. Perspektywa tradycji ignacjańskiej, Kraków 2017; F. Jalics, Towarzyszenie duchowe. Wspólne wzrastanie w wierze, tłum. A. Ziernicki, Kraków 2017; S. T. Muldoon, Jak wychować nastolatka z pomocą duchowości ignacjańskiej, tłum. L. Wierzbowska, Kraków 2017.

${ }_{40}$ Por. Franciszek, Między kanapa a odwaga. Wszystko, co powiedział papież podczas Światowych Dni Młodzieży w Krakowie, Kraków 2016. 
rówieśnicy w tej samej szkole, na podwórku czy w dzielnicy. Miał zatem rację bł. Paweł VI, który zachęcał do zwrócenia szczególnej uwagi na udział młodzieży w dziele ewangelizacji w świecie współczesnym. Papież zauważył: „Powiększająca się jej liczba i wzrastająca obecność jej w społeczeństwie, problemy, jakie ją pasjonują, to wszystko powinno we wszystkich budzić troskę o podanie jej pilnie a mądrze ideału ewangelicznego, celem poznania go i pielęgnowania. Wszakże jest rzeczą konieczną, żeby sami młodzi, należycie uformowani w wierze i modlitwie, stawali się coraz bardziej a postołami swoich rówieśników. Kościół pokłada wielką nadzieję w takiej pomocy..." (EN 72). Pozwólmy zatem ewangelizować młodym w Kościele i na jego peryferiach. Formujmy animatorów i liderów spośród ludzi młodych, którzy najlepiej rozeznają potrzeby swoich rówieśników oraz zaproponują im najlepsze metody i środki przekazu Dobrej Nowiny.

Katecheza w procesie ewangelizacji staje się nie tylko szansą, lecz wyzwaniem dla współczesnych nauczycieli - ewangelizatorów, którzy winni zmierzać do wychowania swoich uczniów w wierze, aktywnych w swoich grupach i wspólnotach kościelnych, otwartych i prowadzących dialog ze światem. Z nowym zapałem, z wykorzystaniem nowych metod i środków mają głosić kerygmat - podstawowe elementy wiary, inspirując w rzeczywistym procesie nawrócenia, pomagając w wyborze i przeżywaniu Ewangelii w życiu codziennym, uzdalniając do uzasadnienia nadziei oraz dodając odwagi do realizacji powołania misyjnego przez świadectwo życia (por. DOK 194). Świadomość ewangelizacyjna inspiruje dynamiczny proces dydaktyczny, na który składają się różne momenty zintegrowane ze sobą: nauczanie, wychowanie i towarzyszenie; wysiłek słuchania echa słowa Bożego (znak, Duch Święty, Pismo Święte, przeżycie religijne) i rozeznania tego, co jest zgodne z Ewangelią, co prowadzi do cierpliwego dojrzewania wewnętrznego uczniów oraz ich zaangażowania w życie Kościoła. 


\section{Summary}

\section{Lekcja religii szansą dla ewangelizacji}

W Kościele istnieje ciągła potrzeba głoszenia Ewangelii młodym. Kościół pragnie dobrze rozeznać i zidentyfikować najbardziej skuteczne sposoby głoszenia Dobrej Nowiny kolejnym pokoleniom. Lekcja religii może stać się miejscem głoszenia Dobrej Nowiny. Środowisko szkolne ewangelizatorzy mogą ożywić przez takie treści, takie środki, taką dynamikę, które natchnione są Duchem Bożym. Od starożytności w Kościele są obecne różne modele ewangelizacji. Ewangelizacja ta zawsze czerpała ze słowa Bożego. Współczesny ewangelizator powinien najpierw rozeznać sytuację, w której przychodzi mu zwiastować słowo Boże i posłużyć się najbardziej odpowiednią strategią ewangelizacji. Te strategie są możliwe do wykorzystania w katechezie. Dziś katecheza korzysta z wielu metod ewangelizacji. Często spotyka się w niej metody wypracowane w Szkole Nowej Ewangelizacji. To staje się szansą dotarcia z orędziem Ewangelii do nowych pokoleń i rozbudzenia w nich radości wiary.

Słowa kluczowe: lekcja religii, katecheza, ewangelizacja, szkoły nowej ewangelizacji

\section{The Lesson of Religious Education as a Chance for Evangelization}

There is a constant need to preach the Gospel to young people in the Church. The Church wants to realize and identify the most effective ways to proclaim the Good News to the next generations. The lesson of religious education can become a place to preach the Good News. Evangelizers can revitalize the school environment through such content, such methods and such dynamics that are inspired by the Spirit of God. Various models of evangelization have been present in the Church since ancient times. This evangelization has always derived from the Word of God. The contemporary evangelist should first realize the situation in which he announces the Word of God and later should use the most appropriate strategy of evangelization. These strategies may be used during catechesis / religious education. Nowadays, it uses many methods of evangelization. One may often encounter the methods developed at the School of New Evangelization. This becomes an opportunity to deliver the message of the Gospel to the new generations and to awaken the joy of faith in them.

Keywords: lessons of religious education, catechesis/religious education, evangelization, the schools of new evangelization 


\section{Bibliografia}

Barbi A., Modelli di evangelizzazione a partire della prassi della prima comunitá cristiana, „Credere Oggi” 32 (2012) 191, s. 54-67.

Bianchi E., Sztuka rozeznania duchowego, „L'Osservatore Romano” 37 (2017) 9, s. $49-50$.

Blachnicki F., Charyzmat „Światło-Życie”. Teksty podstawowe, Krościenko 1987.

Blachnicki F., Została nam powierzona Ewangelia. Wykłady z kerygmatyki czyli teorii ewangelizacji, Kraków 2007.

Cencini A., Od wychowania do formacji, tłum. D. Piekarz, Kraków 2005.

Dyk S., Nowa ewangelizacja. Konkretne wyzwanie, Gubin 2015.

Ewangelizować czy katechizować, red. S. Dziekoński, Warszawa 2002.

Formacja głosicieli Ewangelii. Jak przygotować katechetów - nauczycieli religii do podjęcia nowej ewangelizacji?, red. W. Lechów, Szczecin 2015 (Studia i Rozprawy, 38).

Franciszek, Adhortacja apostolska Evangelii gaudium.

Franciszek, Błogosławieni miłosierni. Słowa do młodych, Kraków 2016.

Franciszek, Między kanapa a odwaga. Wszystko, co powiedział papież podczas Światowych Dni Młodzieży w Krakowie, Kraków 2016.

Hahn S., Nieście i przyjmujcie Dobrą Nowinę. Wyzwania Nowej Ewangelizacji, tłum. M. Bilikiewicz, Poznań 2015.

Haręzga S., Stowo o „dzis”", „Pastores” 36 (2007) 3, s. 7-15.

Jalics F., Towarzyszenie duchowe. Wspólne wzrastanie w wierze, tłum. A. Ziernicki, Kraków 2017.

Jan Paweł II, Adhortacja apostolska Catechesi tradendae, Watykan 1979.

Jan Paweł II, Przemówienie podczas Zgromadzenia Plenarnego CELAM, 9 marca 1983, Port-au-Prince, Haiti, „L'Osservatore Romano” (wyd. pol.) $1983 \mathrm{nr}$ 4, s. 29.

Jan Paweł, List apostolski Novo millennio ineunte.

Kamiński Ł., Aktualizcja Pisma Świętego według dokumentu Papieskiej Komisji Biblijnej „Interpretacja Biblii w Kościele” jako nowy sposób odniesienia słowa Bożego do życia, „Ruch Biblijny i Liturgiczny" 69 (2013) 3, s. 197-215.

Katecheza ewangelizacyjna w rodzinie, parafii, szkole, red. S. Dziekoński, Warszawa 2002.

Katecheza ewangelizacyjna. Poszukiwanie koncepcji, red. P. Mąkosa, Lublin 2010.

Kochel J., Język kerygmatyczny w przekazie wiary, „Biuletyn Edukacji Medialnej” 1 (2014), s. 55-70.

Kochel J., Katecheza misyjna w Ewangelii Łukasza i Dziejach Apostolskich. Biblijnokatechetyczne studium narracyjne, Opole 2013 (Opolska Biblioteka Teologiczna, 133).

Kochel J., Kerygmat jako treść nowej ewangelizacji, w: Nowa ewangelziacja dla nowej katechezy, red. P. Mąkosa, s. 23-30.

Kochel J., Marek Z., Pedagogia biblijna w katechezie, Kraków 2012.

Kochel J., Pedagogia Nowego Człowieka ks. Franciszka Blachnickiego, „Katecheta” 60 (2016) z. 3, s. 135-143. 
Królikowski M., Aktywno-uczestnicząca metoda kursów nowej ewangelizacji. Podstawy teoretyczne i praktyczne, „Przegląd Homiletyczny” 17 (2013), s. 147-157.

Marek Z., Pedagogika towarzyszenia. Perspektywa tradycji ignacjańskiej, Kraków 2017.

Martini C. M., „Tojest Pan!”. Rekolekcje dla osiemnastolatków, tłum. H. Musiał, Kraków 1994.

Martini C. M., Głosiciel Ewangelii u św. Łukasza, tłum. S. Obirek, Kraków 1993.

Martini C. M., Kochać Jezusa. Medytacja nad Ewangelia św. Jana, tłum. A. Sobejko, Kraków 2003.

Martini C. M., Ludu mój, wyjdź z Egiptu, tłum. S. Obirek, Kraków 1989.

Martini C. M., Słownik duchowy. Mały przewodnik dla duszy, tłum. H. Bzikot, Kraków 1999.

Martini, Żyć wartościami Ewangelii, tłum. M. E. Nowak, Wrocław 1999.

Muldoon S. i T., Jak wychować nastolatka z pomoca duchowości ignacjańskiej, tłum. L. Wierzbowska, Kraków 2017.

Nowa ewangelizacja nowej katechezie, red. P. Mąkosa, Rzeszów 2013.

Nowa ewangelizacja. Kerygmatyczny impuls w Kościele, red. P. Sowa, K. Kaproń, Gubin 2012 (Seria Nowej Ewangelizacji).

Offmański A., Koncepcja katechezy o charakterze ewangelizacyjnym według zasad katechumenatu, Szczecin 2010.

Prado Flores J. H., Formacja uczniów, tłum. M. Bigiel, Łódź 1992.

Prado Flores J. H., Idźcie i ewangelizujcie ochrzczonych, tłum. B. K. Jakubowski, Poznań 2016.

Prado Flores J. H., Nowi ewangelizatorzy dla Nowej Ewangelizacji, tłum. B. K. Jakubowski, Poznań 2013.

Prado Flores J. H., Sekret Pawła. Zawodnik Jezusa Chrystusa, tłum. M. Bigiel, Łódź 2007.

Puchalski G., Katecheza w kontekście nowej ewangelizacji w nauczaniu Jana Pawła II, Olsztyn 2002.

Rzeszowski W., Odnowa katechezy w świetle ewangelizacyjnych zadań Kościoła nakreślonych w encyklice Jana Pawła II „Redemptoris misio”, Warszawa 2001.

Sepioło A., Jak pomóc bierzmowanym zostać w Kościele? Doświadczenie diecezji gliwickiej, „Homo Dei” 84 (2015) nr 2, s. 43-51.

Sepioło A., Kasperczyk J., Młodzi na progu. Materiały do pracy z młodzieża przy parafii. Przygotowanie do bierzmowania, Gliwice 2010.

Sepioło A., Nowa ewangelizacja. Śladami Jana Pawła II, Kraków 2001.

Skiba P., Katecheza ewangelizacyjna w nowych ruchach $i$ wspólnotach kościelnych. Studium katechetyczne wybranych ruchów i wspólnot kościelnych, Lublin 2006.

Szlachetka W., Fenomen szkół nowej ewangelizaacji. Studium socjologiczno-pastoralne, Kraków 2011.

Widenka M., Fenomen katolickich kerygmatycznych szkół nowej ewangelziacji, „Studia Pastoralne" 6 (2010), s. 257-287.

Widenka M., Kerygmatyczne szkoły nowej ewangelizacji w Polsce jako praktyczna realizacja wezwania Jana Pawła II do Nowej Ewangelizacji, Katowice 2010. 
Wilk J., Charakterystyka izadania przełożonych wspólnoty chrześcijańskiej według Listów Pasterskich. Studium biblijno-pragmatyczne, Katowice 2015 (Studia i Materiały WT UŚ w Katowicach, 81).

Włodarczyk S., Realizacja zbawczego „dziš" w Chrystusie. Sēmeron w soteriologii Eukasza, Lublin 1989.

XXV lat nauczania religii w polskiej szkole. Między nadzieja a rzeczywistościa, red. M. Zając, Lublin 2015. 